\title{
Plant Growth, Antioxidative Enzymes and Lipid Peroxidation in Sunflower Seedlings Supplemented With Eichhornia crassipes Organic Fertilizer Under Drought Stress Conditions
}

\author{
Rifandreo Monteiro Barbosa ${ }^{1}$, Paulo Ovídio Batista de Brito ${ }^{1}$, Francisca Raíssa da Silva Costa ${ }^{1}$, \\ Roberto Albuquerque Pontes Filho ${ }^{1}$, Francisco Holanda Nunes Júnior ${ }^{2}$ \& Franklin Aragão Gondim ${ }^{1}$ \\ ${ }^{1}$ Instituto Federal de Educação, Ciência e Tecnologia do Ceará, Maracanaú Campus, Brazil \\ ${ }^{2}$ Instituto Federal de Educação, Ciência e Tecnologia do Ceará, Jaguaribe Campus, Brazil \\ Correspondence: Franklin Aragão Gondim, Instituto Federal de Educação, Ciência e Tecnologia do Ceará \\ (IFCE), Maracanaú Campus, Brazil. Tel: 55-853-878-6300. E-mail: aragaofg@yahoo.com.br
}

$\begin{array}{ll}\text { Received: September 5, } 2018 & \text { Accepted: October 10, } 2018 \quad \text { Online Published: December 15, } 2018 \\ \text { doi:10.5539/jas.v11n1p504 } & \text { URL: https://doi.org/10.5539/jas.v11n1p504 }\end{array}$

The research is financed by IFCE-Maracanaú Campus-Instituto Federal de Educação, Ciência e Tecnologia do Ceará (IFCE), Brasil.

\begin{abstract}
In the semiarid region of the Brazilian Northeast, there is still the occurrence of soils with low concentrations of organic mass and nutrients. Eichhornia crassipes (water hyacinth) is recognized as one of the top ten endemic herbs in the world. However, its accumulation capacity means it can be an alternative source of nutrients. The objective of this study was to analyse the effects of macrophyte organic residue (ROM) on plant growth, antioxidative enzyme activity and membrane lipid peroxidation in leaves and roots of sunflower seedlings submitted to drought stress conditions. The experiment was conducted under greenhouse conditions at the Instituto Federal de Educação, Ciência e Tecnologia do Ceará, Maracanaú Campus, Brazil. Samples of E. crassipes were collected in the Parangaba Lagoon, Fortaleza, Ceará, Brazil. The treatments were: 1) 100\% (by volume) sand; 2) sand + fertilizer (following the recommendation of $80 \mathrm{~kg}$ of N/ha), and 3) sand $+100 \%$ of the recommended nitrogen in macrophytes $(\mathrm{RN})$. In general, the use of ROM caused better seedling growth in relation to the other treatments in all conditions studied. Increases in antioxidative enzyme activity and reductions in the deleterious effects of drought stress on plant growth were observed.
\end{abstract}

Keywords: drought, Helianthus annuus, oxidative stress, water hyacinth

\section{Introduction}

Water deficit is one of the main agricultural problems that reduces crop yields in arid and semiarid regions of the world, including the Brazilian Northeast (Farooq et al., 2009; Niu et al., 2017). These regions present irregular distribution of precipitation, high evaporation rates, and shallow and nutrient-poor soils (Santos et al., 2010). Despite these limiting factors, irrigation practice is the best way to ensure agricultural production, which together with organic fertilization can make soils more fertile and productive (Nobre et al., 2011; Finatto et al., 2013).

Drought stress can cause morphological, physiological and biochemical changes in plants (Ferrari et al., 2015), as well as the restriction of nutrient and water acquisition (Manivannan et al., 2016), in addition to stomatal closure reducing the rate of evapotranspiration. Consequently, the photosynthetic rate may be reduced due to the lower availability of $\mathrm{CO}_{2}$, causing damage to the growth and development of the plants (Ghobadi et al., 2013; Cerqueira et al., 2015).

Drought stress can also alter biochemical processes, thus increasing the production of reactive oxygen species (ROS). In excess, ROS are highly toxic to plants, with the following outstanding: superoxide $\operatorname{radical}\left(\mathrm{O}_{2}^{-}\right)$, hydrogen peroxide $\left(\mathrm{H}_{2} \mathrm{O}_{2}\right)$, singlet oxygen $\left({ }^{1} \mathrm{O}_{2}\right)$ and hydroxyl $(\cdot \mathrm{OH})($ Demidchik, 2015). However, plants have defence mechanisms to combat this oxidative stress, such as the synthesis of non-enzymatic antioxidant compounds and/or the synthesis and activation of antioxidative enzymes such as superoxide dismutase (SOD), 
catalase (CAT), ascorbate peroxidase (APX) and guaiacol peroxidase (GPX) which aim to reduce ROS concentrations (Gill \& Tuteja, 2010; Gonçalves, 2017).

In the semiarid region of the Brazilian Northeast, there is still the occurrence of soils with low concentrations of organic matter and nutrients such as nitrogen and phosphorus (Esteves \& Meirelles-Pereira, 2011). In this region, there is also a large presence of floating macrophytes in the water bodies, which may be related to disturbances in their short flood periods and prolonged dry periods (Pedro et al., 2006; Henry-Silva et al., 2010).

Macrophytes are plant organisms distributed throughout the world in numerous humid environments and which have high nutrient storage capacity (Bonanno \& Lo Giudice, 2010). They are among the groups that produce organic matter and play an important role in the geochemistry of wetlands. In addition, because of their accelerated decomposition, macrophytes when deposited in the soil can enrich it nutritionally (Dibble, 2005; Vodyanitskii \& Shoba, 2015).

Eichhornia crassipes (water hyacinth) is a free-floating macrophyte native to South America, and one of the most studied for phytoremediation purposes (Gupta et al., 2012; Melignami et al., 2015). This species reproduces sexually and asexually and can quickly colonize new areas (Villamagna \& Murphy, 2010). It is present in 65 countries and is recognized as one of the ten main endemic herbs in the world. Its large accumulation can characterize problems such as eutrophication, where this species functions as a bioindicator (Shanab et al., 2010). However, this plant can remove heavy metals, nutrients and sediments from water (Buta et al. 2011). In view of this, E. crassipes could be used in the composition of substrates for plants, functioning as an alternative source of nutrients. In addition, it could be an alternative destination for this waste.

The sunflower (Helianthus annuus L.) is an oleaginous species that has been gaining ground in the Brazilian Northeast because it has a good tolerance to heat and drought. Among the characteristics of this crop, the following stand out: rusticity, high productivity and the quality of its oil, besides the potential for honey production and use in poultry rations (Lira et al., 2009; Souza et al., 2010; Santos et al., 2015).

Thus, the present work analysed the effects of using macrophyte organic residue (ROM) on the initial growth of sunflower $(H$. annuиs L.) plants under conditions of drought stress, evaluating plant growth, antioxidative enzyme activity and membrane lipid peroxidation.

\section{Method}

The experiment was conducted under greenhouse conditions at Instituto Federal de Educação, Ciência e Tecnologia do Ceará (IFCE), Maracanaú campus, Ceará, Brazil, from October to December 2016, totalling 30 days. The mean values of temperature and relative humidity were $30{ }^{\circ} \mathrm{C}$ and $56 \%$, respectively.

Samples of E. crassipes (water hyacinth) were manually removed from the Parangaba Lagoon, Fortaleza, Ceará, Brazil, and arranged to dry in the full sun for 20 days. Subsequently, the dry mass was crushed by a mechanical crusher and sent to the Laboratory of Biochemistry and Plant Physiology of the IFCE Maracanaú campus to finalize the drying process in an oven with forced circulation of air at $60^{\circ} \mathrm{C}$.

The material obtained was called ROM. After this process, a sample of the material was sent for analysis in the Laboratory of Soils/Water of the Federal University of Ceará (Table 1), and the results for nitrogen $(\mathrm{N})$ content were used in calculations of amounts of ROM added to the substrates. For the commercial fertilizer treatment, the data of the analyses performed were provided by the manufacturer Terra Vegetal (Table 1).

Table 1. Chemical analysis of the masses of Eichhornia crassipes and commercial fertilizer used in the composition of substrates for cultivation of sunflower plants (Helianthus annuus L.)

\begin{tabular}{|c|c|c|c|c|c|c|c|c|c|c|c|c|c|c|}
\hline & N-t & $\mathbf{C a}$ & $\mathbf{N a}$ & Mg & $\mathbf{K}$ & $\mathbf{K}_{\mathbf{2}} \mathbf{O}$ & $\mathbf{P}$ & $\mathbf{P}_{2} \mathbf{O}_{5}$ & $\mathbf{S}$ & $\mathbf{F e}$ & & $\mathrm{Cu}$ & $\mathbf{Z n}$ & Mn \\
\hline & \multicolumn{9}{|c|}{ 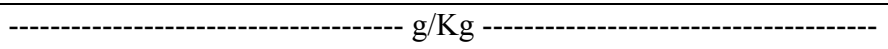 } & \multicolumn{5}{|c|}{ 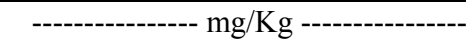 } \\
\hline ROM & 19.6 & 13.3 & 15.3 & 16.4 & 33.2 & 40.5 & 3.9 & 8.9 & 2.8 & 19 & & 13.3 & 15.3 & 16.4 \\
\hline \multirow[t]{3}{*}{ Adubo } & 2.2 & 8.43 & - & 8.10 & 1.52 & 1.85 & 3.9 & 0.98 & - & & 5,5 & 1.80 & 89.3 & 380.1 \\
\hline & *pH & ${ }^{*} \mathbf{C} . \mathbf{E}$ & R.A.S & C.O.T & & & $\mathbf{N H}_{4}$ & $\mathrm{NO}_{3}$ & & $\mathrm{NO}_{2}^{-}$ & $\mathrm{Cl}^{-}$ & & & $\mathrm{CO}_{3}^{-}$ \\
\hline & \multicolumn{3}{|c|}{-------- dS/m --------- } & \multicolumn{3}{|c|}{------- g/kg -------- } & \multicolumn{4}{|c|}{--- Formas de N $(\mathrm{g} / \mathrm{kg})$--- } & \multicolumn{4}{|c|}{-------------- g/Kg ------------ } \\
\hline ROM & 6.6 & 7.52 & 3.35 & 453.3 & 2 & & 14.1 & 3.9 & & 1.1 & 10.1 & 0 & & 0.0 \\
\hline Adubo & 7.6 & - & - & - & - & & - & - & & 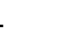 & - & - & & - \\
\hline
\end{tabular}

Note. N-t: total nitrogen; T.O.C: Total Organic Carbon; C/N: carbon nitrogen ratio; C.E: Electric conductivity; S.A.R: sodium adsorption ratio. *Relation of $(1: 10)$. 
Sunflower seeds (cultivar BRS 323) were seeded in plastic vases (5 litres), containing: 1) $100 \%$ (by volume) of sand; 2) sand + commercial fertilizer $(11.8 \% \mathrm{~N}$ concentrations calculated following the recommendation of 80 $\mathrm{kg}$ of $\mathrm{N} / \mathrm{ha}$ ), and 3) sand $+100 \%$ of the recommended macrophyte nitrogen (RN) following the recommendation of $80 \mathrm{~kg}$ culture of $\mathrm{N} / \mathrm{ha}$ ). The treatments were irrigated at $80 \%$ of field capacity, which was calculated based on the total weight of the vase when the substrate was filled with water.

The mass of the plastic vases was recorded at the beginning of the experiment, and the daily evapotranspiration was replaced with distilled water. At 21 days after sowing (DAS), half of each group of seedlings described above was submitted to irrigation suspension. A collection was performed at 28 DAS ( 7 days under water drought).

The experimental design was completely randomized, with a 2 (irrigated or non-irrigated) $\times 3$ (sand, sand + commercial fertilizer, sand $+100 \% \mathrm{RN}$ in macrophyte) factorial arrangement with seven replicates, each consisting of a vase with two plants. The data were submitted to analysis of variance (ANOVA), and the means were compared by the Tukey test $(P \leq 0.05)$ using Assistat 7.7 statistical software; graphs were plotted using Sigma Plot 11.0 software.

The leaf area was measured with a scanner-type meter (model AM350, ADC Bioscientific Ltd.). For the determination of dry mass, the plants were separated into roots, stems and leaves, then placed in an oven with forced circulation of air at $60{ }^{\circ} \mathrm{C}$ until a constant mass was obtained. Each sample was then weighed using an analytical balance.

For the determination of antioxidative enzyme activity, fresh leaf and root extracts were prepared according to Nunes Junior et al., (2017). Thus, the activity of the enzymes CAT, GPX, APX and SOD was determined by spectrophotometry.

The activity of GPX was determined by the method of Kar \& Mishra (1976), and the reaction was accompanied by an increase in absorbance at $470 \mathrm{~nm}$ due to the formation of tetraguaiacol; CAT was determined according to Havir and McHale, (1987) by a decrease in absorbance at $240 \mathrm{~nm}$ due to $\mathrm{H}_{2} \mathrm{O}_{2}$ consumption; the oxidation of ascorbate was measured by a decrease in absorbance at $290 \mathrm{~nm}$, and that of SOD by the method of Beauchamp \& Fridovich, (1971), the reaction being measured by an increase in absorbance at $560 \mathrm{~nm}$ due to the production of blue formazan resulting from the photoreduction of p-nitroblue tetrazolium (NBT). Lipid peroxidation was determined by measuring the amount of malondialdehyde (MDA) produced by the thiobarbituric acid (TBA) reaction (Buege \& Aust, 1978).

The activity of CAT, APX and GPX was expressed in $\mu \mathrm{mol} \mathrm{H}_{2} \mathrm{O}_{2} \min ^{-1} \mathrm{~g}^{-1} \mathrm{MF}$, and that of SOD in UA g ${ }^{-1} \mathrm{MF}$, where MF represents fresh matter and one UA (unit of enzyme activity) is defined as the amount of enzyme

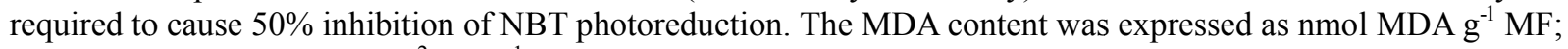
leaf area was expressed as $\mathrm{cm}^{2}$.plant ${ }^{-1}$, and the dry mass as $\mathrm{g} / \mathrm{plant}$.

\section{Results}

In the experimental conditions used, it was verified that the treatment containing ROM caused greater growth of sunflower plants when compared to the sand and commercial fertilizer treatments in control and drought stress conditions. It was observed that the plants of the control group (C) had greater growth than those of the drought stress group (D) at 28 DAS (Figure 1).

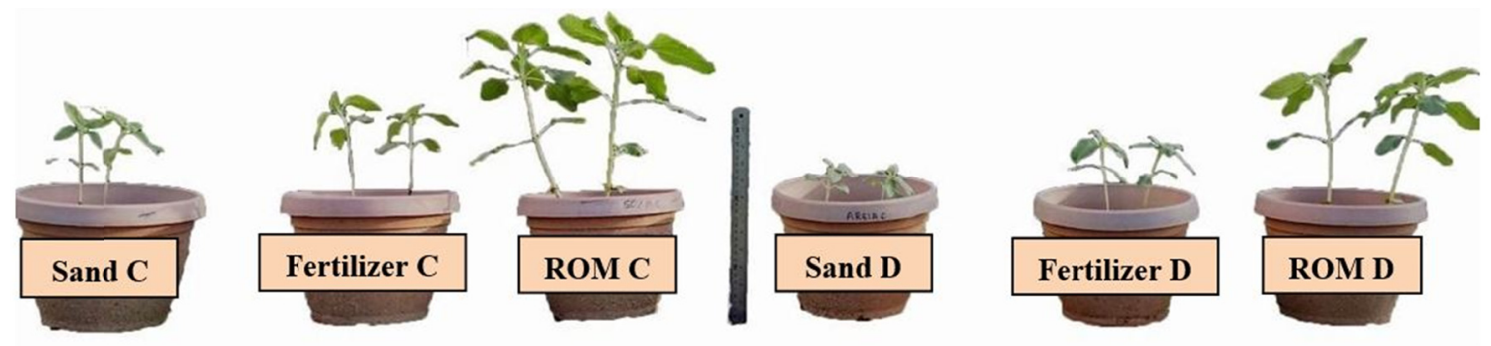

Figure 1. Sunflower plants on substrates containing sand, commercial fertilizer and macrophyte organic residue (ROM) under control conditions (C) and drought stress (D) at 28 DAS (7 days under drought stress) 
For the variable shoot dry mass (SDM) (Figure 2A), it was verified that at 28 DAS, sunflower plants growing on substrate containing ROM presented higher values when compared to sand and fertilizer treatments in both control and drought stress conditions. It was also observed that, on average, the control treatment containing ROM had values 518 and $184 \%$ higher than for the sand and fertilizer treatments, respectively. For treatment under drought stress conditions, SDM was 314 and $94 \%$ higher than with sand and fertilizer, respectively. It was found that the SDM for the ROM control treatment was 70\% higher than for ROM under drought stress.

For root dry mass (RDM) (Figure 2B), it was observed that plants growing on substrates containing ROM under control conditions had values $300 \%$ higher than for sand and fertilizer treatments. Under conditions of drought stress, the RDM for the ROM treatment was 120 and $40 \%$ higher than for sand and fertilizer, respectively.

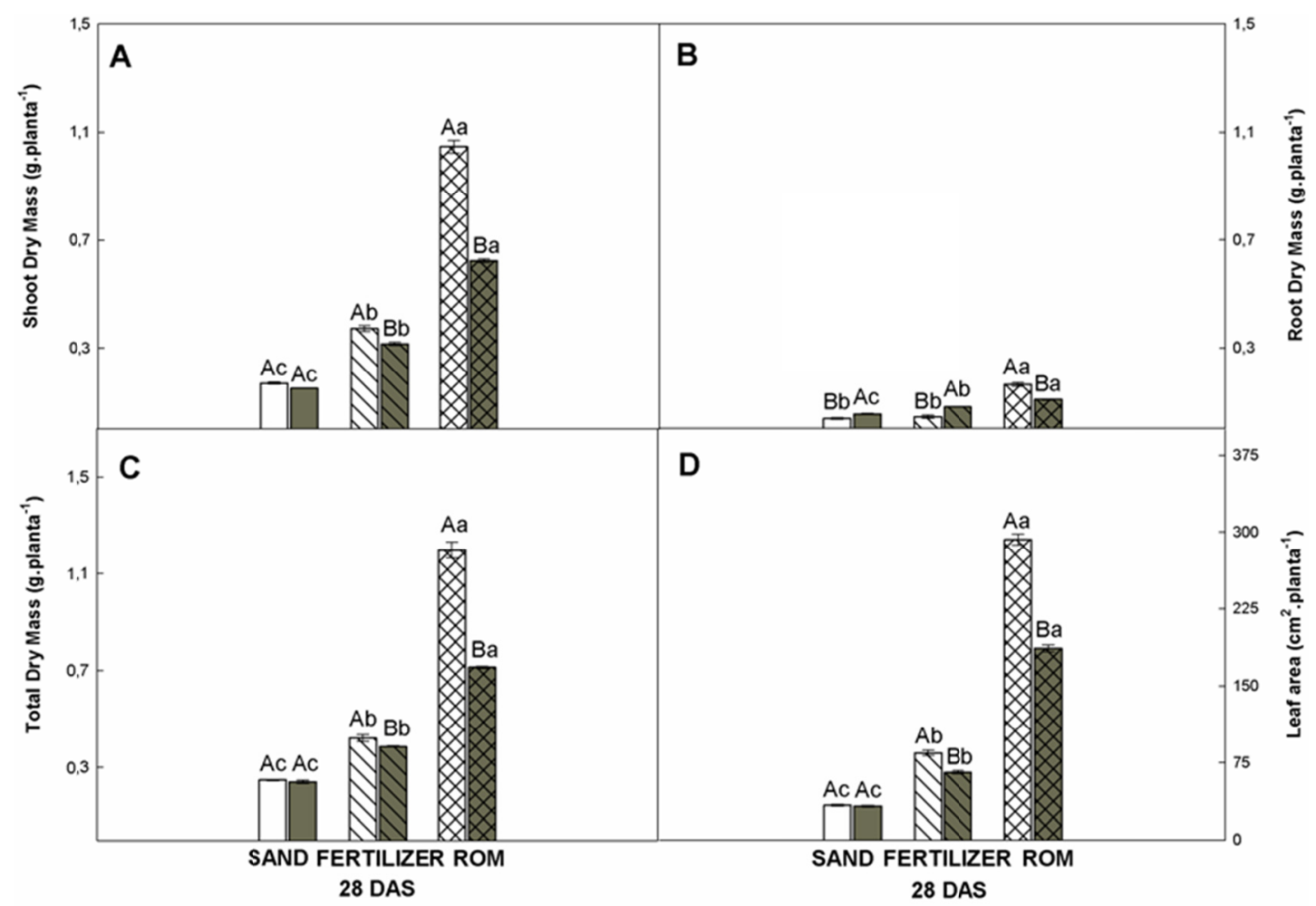

Figure 2. Shoot (A), root (B) and total dry mass (C) and leaf area (D) of sunflower plants 28 days after sowing (7 days after irrigation suspension) on substrates containing sand, commercial fertilizer and macrophyte organic residue (ROM) under control conditions (white bars) or drought stress (gray bars). Different lowercase letters indicate significant differences between the substrates (sand, fertilizer and ROM), and different uppercase letters indicate significant differences between condition types (control and drought stress), according to the Tukey test $(P \leq 0.05)$. Bars represent the mean values of seven replicates \pm the standard error

For total dry mass (TDM), at 28 DAS, sunflower plants growing on substrate containing $100 \%$ RN in macrophytes presented results 380 and $190 \%$ higher, respectively, than for sand and fertilizer treatments; in drought stress conditions, TDM was 200 and $82 \%$ higher than sand and fertilizer, respectively. Within the ROM treatment, plants under control conditions had 70\% more TDM than those under drought stress.

In general, drought stress caused a reduction in leaf area in all treatments when compared to control groups (Figure 2D). Under control conditions, the ROM treatment in relation to the sand and fertilizer treatments provided 770 and $250 \%$ more leaf area, respectively. Even in conditions of drought stress, leaf area was $466 \%$ higher than for sand and $190 \%$ higher than for fertilizer. Additionally, it was verified that the plants given the treatment containing ROM in the control conditions presented a leaf area $61 \%$ higher than for those under drought stress.

Figure 3 presents the activity of the enzymes SOD, CAT, APX and GPX in leaves of sunflower seedlings at 28 DAS (7 days after suspension of irrigation). 
CAT activity in leaves (Figure 3A) was higher in treatments supplemented with ROM. In addition, control seedlings supplemented with ROM differed by $16 \%$ in relation to those submitted to stress and showed, on average, activity 162 and $51 \%$ higher than for sand and fertilizer treatments, respectively, under control conditions, and 455 and $112 \%$ higher under irrigation suspension conditions.

SOD activity in leaves of sunflower seedlings (Figure 3B) was higher in treatments supplemented with ROM. In addition, control seedlings supplemented with ROM differed by $4 \%$ in relation to those submitted to stress and showed, on average, activity 7 and 5\% higher than for sand and fertilizer treatments, respectively, under control conditions, and 11 and 5\% higher under drought stress conditions.

For APX activity in the leaves (Figure 3C), plants growing on substrate containing $100 \% \mathrm{RN}$ in macrophytes presented results 35 and $25 \%$ higher than for sand and fertilizer treatments, respectively, under control conditions. Even under conditions of drought stress, the treatment containing ROM resulted in superior APX activity, by 65 and $54 \%$ compared to sand and fertilizer, respectively. Within the ROM treatment, the plants under control conditions had APX activity superior by $30 \%$ when compared to those under drought stress.

The GPX activity in the leaves (Figure 3D) was higher in plants supplemented with ROM. In addition, control seedlings supplemented with ROM differed by $43 \%$ in relation to those submitted to stress and had, on average, GPX activity 43 and $65 \%$ higher than for the sand and fertilizer treatments, respectively, in the control conditions, and 56 and $26 \%$ higher under irrigation suspension conditions.

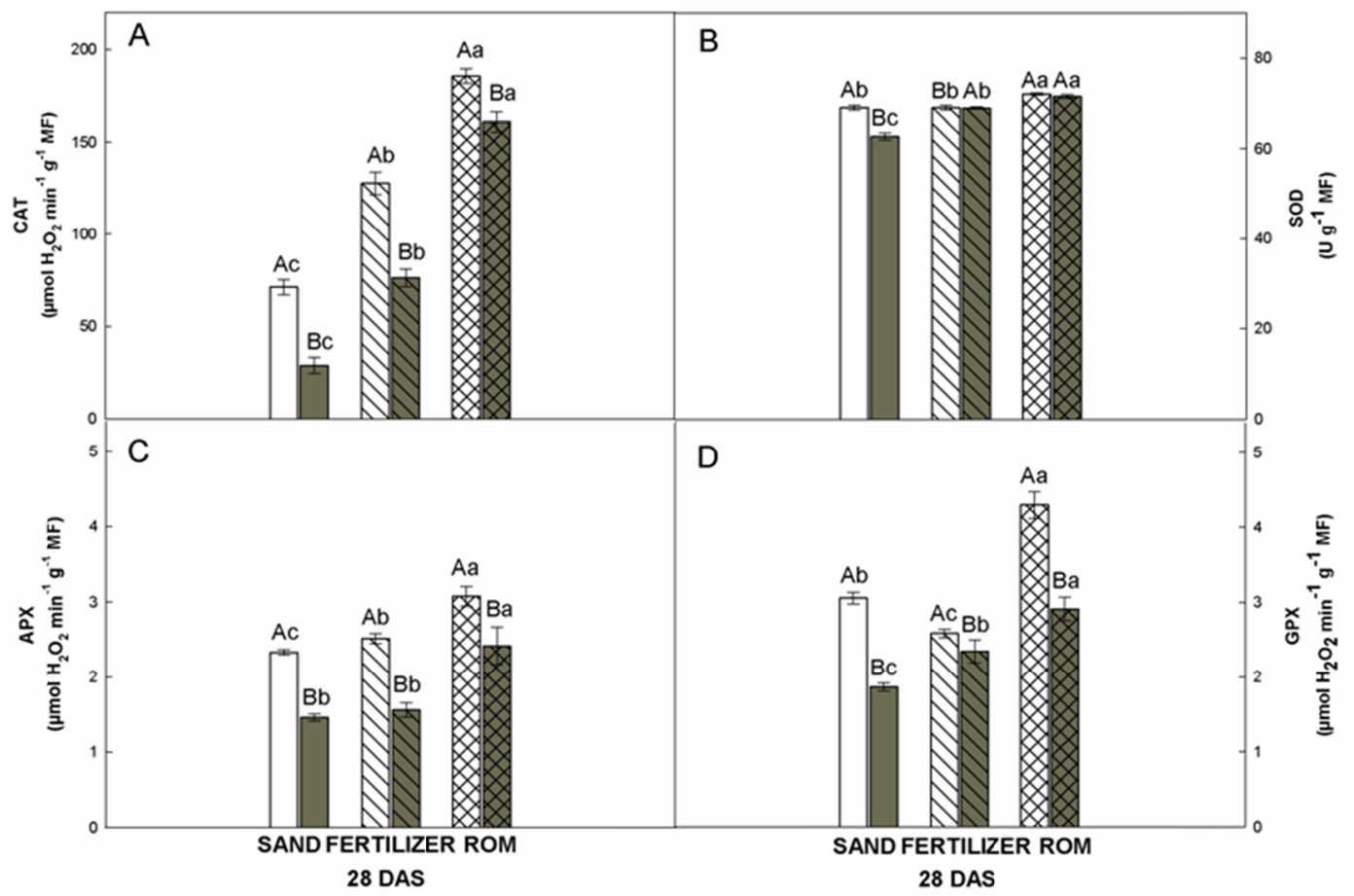

Figure 3. Activities of catalase-CAT (A), superoxide dismutase-SOD (B), ascorbate peroxidase-APX (C) and guaiacol peroxidase-GPX (D) in leaves of sunflower plants at 28 days after sowing ( 7 days after irrigation suspension) on substrates containing sand, fertilizer commercial and Macrophyte Organic Residue (ROM) under control conditions (white bars) or drought stress (gray bars). More details in the legend of Figure 2

In the present work, at 28 DAS (7 days after the suspension of the irrigation), no CAT activity was observed in the roots of the sunflower seedlings. Thus, in Figure 4, the activity of SOD, APX and GPX are presented. No CAT activity was observed in other studies with sunflowers under drought stress either, such as that of Nunes Junior et al. (2017) using landfill percolation as a substrate, and that of Braga et al. (2017) who tested organic shrimp residue.

SOD activity in the roots (Figure 4A) was higher in plants under control conditions supplemented with ROM. Additionally, there were no statistical differences between control conditions and drought stress within the ROM treatment. 
For APX activity in the roots (Figure 4B), sunflower plants growing on substrate containing ROM presented results higher by 20 and $15 \%$, respectively, than for sand and fertilizer treatments under control conditions. Even under conditions of drought stress, the treatment containing ROM resulted in APX activity 10 and 14\% higher than for sand and fertilizer, respectively. Within the ROM treatment, plants under control conditions had 33\% higher APX activity when compared to those under drought stress.

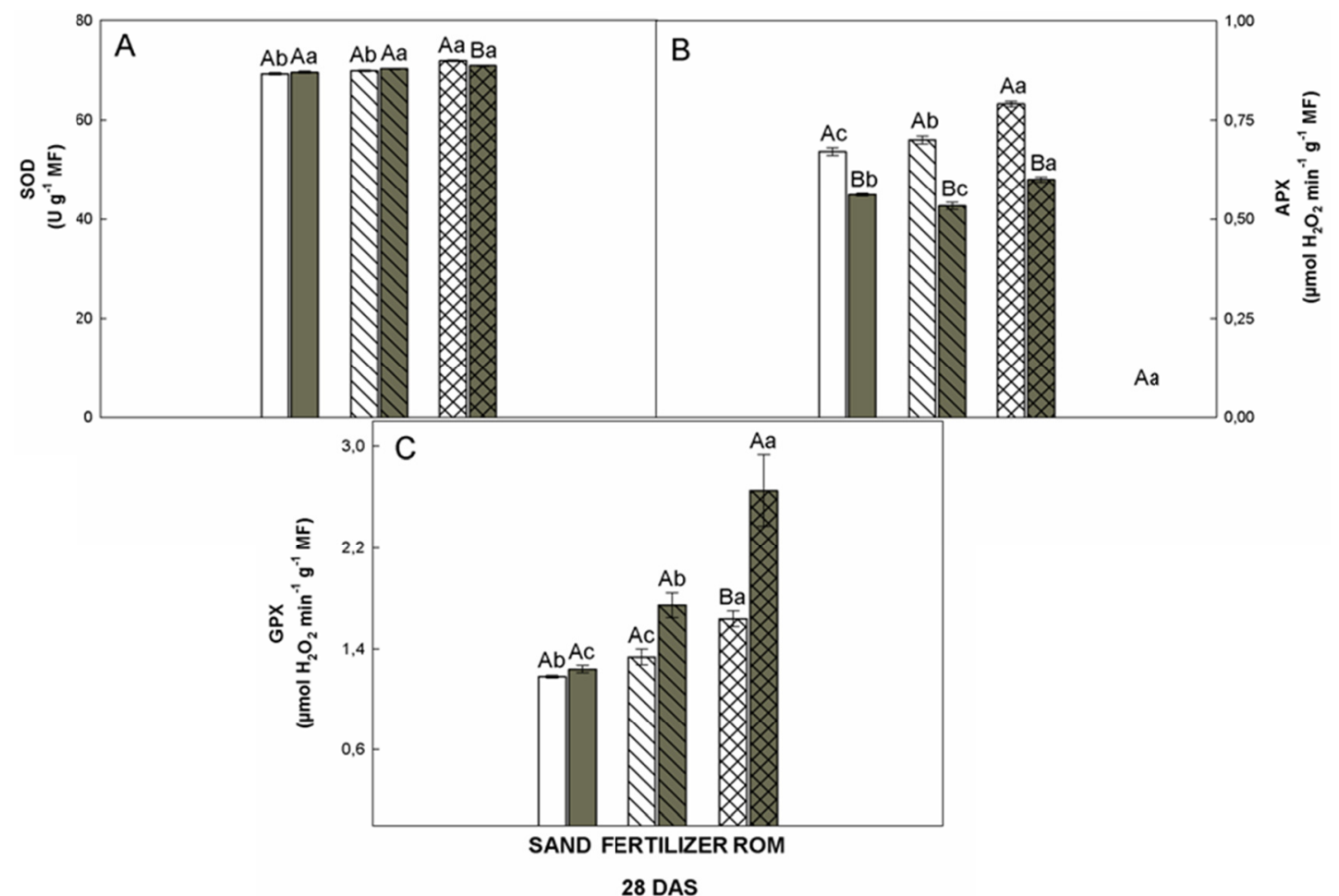

Figure 4. Activities of superoxide dismutase-SOD (A), ascorbate peroxidase-APX (B) and guaiacol peroxidase-GPX (C) in roots of sunflower plants at 28 days after sowing (7 days after irrigation suspension) on substrates containing sand, fertilizer commercial and Macrophyte Organic Residue (ROM) under control conditions (white bars) or drought stress (gray bars). More details in the legend of Figure 2

The GPX activity in the roots (Figure 4C) was higher in plants supplemented with ROM under drought stress, differing by $63 \%$ in relation to the control plants of the same treatment, and showed, on average, activity higher by 114 and $52 \%$ than for the sand and fertilizer treatments, respectively.

In general, plants subjected to drought stress presented the highest levels of MDA, especially for sand and fertilizer treatments, which had 93 and 50\% more MDA, respectively, when compared to the treatment containing $100 \%$ RN. Thus, plants supplemented with ROM, both under control conditions and drought stress, had the lowest MDA content. 


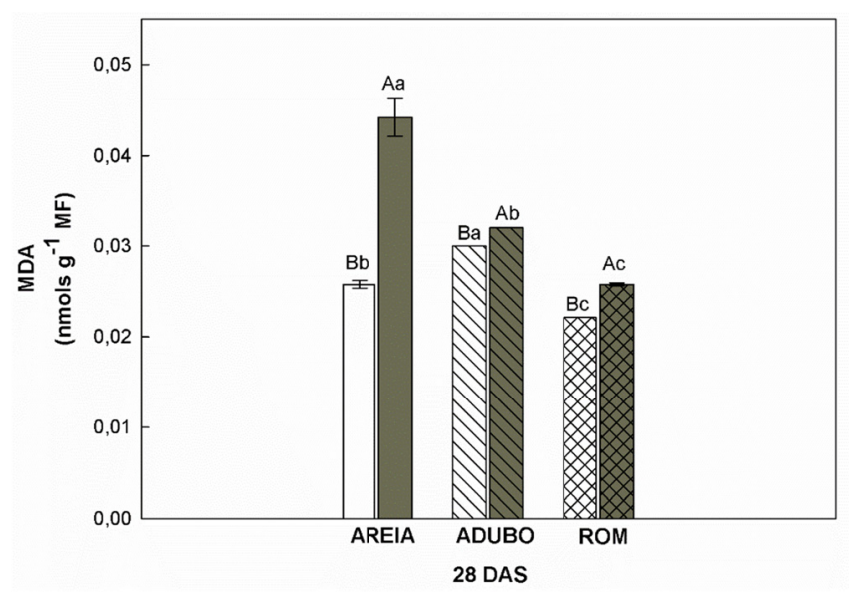

Figure 5. Malondialdehyde (MDA) contents in leaves of sunflower plants at 28 days after sowing (7 days after irrigation suspension) on substrates containing sand, commercial fertilizer and Macrophyte Organic Residue (ROM) under control conditions (white bars) or drought stress (gray bars). More details in the legend of Figure 2

\section{Discussion}

In general, a reduction in plant growth was observed due to the applied water restriction (Figures 1 and 2). However, the use of ROM in the substrate minimized this damage. This is due to plant growth depending on cell division and expansion, the latter being conditioned to the turgescence pressure, a process affected by poor availability of water in the soil or by excessive transpiration (Santos et al., 2014).

This behaviour was like that observed in other studies, such as that of Carneiro (2011) in which young sunflower plants were sensitive to water deficit; to minimize deleterious effects, the plants reduce stomatal opening, maximizing the efficiency of their use of water.

Nobre et al. (2017) also observed reductions of SDM in sunflower plants under stress. Guedes Filho et al. (2011) observed that nitrogen concentration and water content in the soil positively influenced all variables in a sunflower crop (cv. EMBRAPA 122/V-2000) corresponding to dry phytomass production. Similarly, Dutra et al. (2012) observed significant differences in the dry mass of sunflower plants under control and drought stress conditions; they attributed this behaviour to the addition of water by irrigation.

The results for growth were also reflected in the leaf area (Figure 2). In general, irrigated and nitrogen-supplemented treatments were superior. Similar results were found by Nobre et al. (2017); they concluded that a higher nitrogen content causes an increase in the leaf area of sunflower plants (cv. EMBRAPA 122/V-2000) under stress, and Barbosa et al. (2018) showed that sunflower plants supplemented under different concentrations of macrophyte residue had a high leaf area.

A decrease in leaf area under drought stress was also observed by Nascimento et al. (2011). A reduction in leaf area represents an important mechanism for acclimatization to drought stress, as it reduces water losses through stomatal flow and contributes to the maintenance of a high water potential in the plant.

In the present study, the use of ROM caused high leaf area, which could indicate a better efficiency of water use, and the existence of a larger area available for photosynthesis.

The high growth of the plants (Figures 1 and 2) supplemented with ROM in comparison to the other treatments can also be explained by the high activity of antioxidant enzymes (Figures 3 and 4) as well as reductions in lipid peroxidation (Figure 5).

SODs are metalloenzymes that are considered the first line of defence against ROS in which they catalyse the dismutation of two ${ }^{\circ} \mathrm{O}_{2}$ radicals, generating $\mathrm{H}_{2} \mathrm{O}_{2}$ and $\mathrm{O}_{2}$ (Barbosa et al., 2014). CAT is one of the most effective enzymes in defence against oxidative processes (Akcay et al., 2010), and is still believed to be the major $\mathrm{H}_{2} \mathrm{O}_{2}$-killing enzyme (Barbosa et al., 2014).

In general, in the leaves, the CAT activity for the irrigated treatments was superior to that under drought stress. However, treatments containing ROM had significantly higher CAT activity than the other treatments. Thus, the data corroborate those of Eyidogan and Oz (2007) who demonstrated that an increase in CAT activity causes a reduction in $\mathrm{H}_{2} \mathrm{O}_{2}$ accumulation with consequent reduction of lipid peroxidation. 
In addition, both the leaves and roots of plants treated with ROM showed higher APX and GPX activity when compared to the other treatments. This may be associated with the behaviour of these species which function as a secondary mechanism in the elimination of ROS when compared to CAT, which first contributes to $\mathrm{H}_{2} \mathrm{O}_{2}$ detoxification (Bhatt \& Tripathi, 2011).

In addition to these defence mechanisms, it is important to quantify lipid peroxidation, which produces MDA which is used to determine process intensity in the lipids of plant cell membranes. Thus, an increase of this substance is directly associated with indications of oxidative stress (Hendges et al., 2015).

It should be noted that in both stress and control conditions, the treatments containing ROM had the lowest MDA levels. Moreover, similar results were found in other studies such as that of Messchmidt et al. (2015) who observed high levels of MDA in Prunus spp. under conditions of drought, and Silva (2010) who found a significant increase in the concentrations of MDA in sugarcane plants also submitted to drought.

Maia et al. (2012) concluded that increases in the activity of enzymes such as SOD, APX and CAT are associated with a reduction of lipid peroxidation (MDA) in plants under conditions of drought stress. Thus, it is suggested that the use of ROM causes greater antioxidative enzyme activity and provides a reduction in lipid peroxidation and the deleterious effects of drought stress.

\section{Conclusions}

In the present experimental conditions, the use of ROM caused an increase in plant growth (SDM, RDM, TDM and leaf area) and antioxidant enzyme activity (SOD, CAT, APX and GPX) which contributed to a reduction of membrane lipid peroxidation (MDA) and the deleterious effects of drought stress, both under control conditions and drought stress, when compared to the other treatments.

Thus, the use of dried and crushed E. crassipes to add nutrients and organic matter to the soil is suggested.

Subsequent studies should be carried out to verify the use of this residue on a large scale and to act as an environmentally correct destination.

\section{Acknowledgements}

The autors are grateful to Instituto Federal de Educação, Ciência e Tecnologia do Ceará-Campus Maracanaú for the scholarship and EMBRAPA for the seeds ceded.

\section{References}

Akcay, U. C., Ercan, O., Kavas, M., Yildiz, L., Ylmaz, C., Oktem, H. A., \& Yucel, M. (2010). Drought-induced oxidative damage a ond antioxidant responses in peanut (Arachishygaeae L.) seedling. Plant Growth Regulation, 61(1), 21-28. https://doi.org/10.1007/s10725-010-9445-1

Barbosa, M. R., Silva, M. A. de, Willadino, L., Ulisses, C., \& Camara, T. R. (2014). Geração e desintoxicação enzimática de espécies reativas de oxigênio em plantas. Ciência Rural, 44(3), 0103-8478. https://doi.org/ $10.1590 / \mathrm{S} 0103-84782014000300011$

Barbosa, R. M., Silva, G. D., Brito, P. O. B., Braga, B. B., \& Gondim, F. A. (2018). Resíduo orgânico de Eichhornia crassipes como fonte de nutrientes no crescimento inicial de plantas de girassol. Revista Brasileira de Agroecologia, 12(4), 1980-9735.

Beauchamp, C., \& Fridovich, I. (1971). Superoxide dismutase: Improved assays and an assay applicable to a crylamide gels. Analytical Biochemistry, 44(1), 276-287. https://doi.org/10.1016/0003-2697(71)90370-8

Bhatt, I., \& Tripathi, B. N. (2011). Plant peroxiredoxins: Catalytic mechanisms, functional significance and future perspectives. Biotechnology Advances, 29(1), 850-859. https://doi.org/10.1016/j.biotechadv.2011. 07.002

Bonanno, G., \& Lo Giudice, R. (2010). Heavy metal bioaccumulation by the organs of Phragmites australis (common reed) and their potential use as contamination indicators. Ecological Indicators, 10(1), 639-645. https://doi.org/10.1016/j.ecolind.2009.11.002

Braga, B. B., Gondim, F. A., Junior, F. H. N., De Oliveira Paiva, S. I., Martins, R. M., \& Pontes Filho, R. A. (2017). Efeitos da suplementação com resíduo da atividade da carcinicultura em plantas de girassol submetidas a condições de estresse hídrico. Irriga, 22(3), 591-605.

Buege, J. A., \& Aust, S. D. (1978). Microsomal lipid peroxidation. Methods in Enzymology, 52(1), 302-310. https://doi.org/10.1016/S0076-6879(78)52032-6 
Buta, E., Paulette, L., Mihaiescu, T., Buta, M., \& Cantor, M. (2011). The Influence of Heavy Metals on Growth and Development of Eichhornia crassipes Species, Cultivated in Contaminated Water. Notulae Botanicae Horti Agrobotanici Cluj-Napoca, 39(2), 135-141. https://doi.org/10.15835/nbha3926095

Carneiro, M. M. L. C., Deuner, S., Oliveira, P. D. De, Teixeira, S. B., Sousa, C. P., \& Bacarin, M. (2011) Atividade antioxidante e viabilidade de sementes de girassol após estresse hídrico e salino. Revista Brasileira de Sementes, 33(4), 752-761. https://doi.org/10.1590/S0101-31222011000400017

Cerqueira, R. C., Costa, J. M., Chaves, M. M., \& Rodrigues, J. D. (2015). Fisiologia e metabolismo foliar em duas variedades de videira sujeitas a um ciclo de défice hídrico e reidratação. Revista Brasileira de Ciências Agrárias, 10(2), 211-217, 1981-1160.

Demidchik, V. (2015). Mechanisms of oxidative stress in plants: From classical chemistry to cell biology. Environmental and Experimental Botany, 109(1), 212-228. https://doi.org/10.1016/j.envexpbot.2014.06.021

Dibble, E. D. (2005). O papel ecológico das plantas aquáticas nos corredores de biodiversidade. Cadernos da Biodiversidade, 5(1), 4-13.

Dutra, C. C., Ferreira Do Prado, E. A., Ramão Paim, L., \& Scalon, S. D. P. Q. (2012). Desenvolvimento de plantas de girassol sob diferentes condições de fornecimento de água. Semina: Ciências Agrárias, 33(1), 2657-2668. https://doi.org/10.5433/1679-0359.2012v33Supl1p2657

Esteves, F. D. A., Meirelles-Pereira, F. (2011). Eutrofização artificial. Fundamentos da limnologia (3rd ed., pp. 625-656). Rio de Janeiro, Editora Interciência.

Eyidogan, F., \& Oz, M. T. (2007). Effect of salinity on antioxidant responses of chickpea seedlings. Acta Physiology Plant, 29(1), 48-493. https://doi.org/10.1007/s11738-007-0059-9

Farooq, M., Wahid, A., Kobayashi, N., Fujita, D., \& Basra, S. M. A. (2009). Plant drought stress: Effects, mechanisms and management. Susteneable Agiculture. Spriger, Dordrecht, 29(1), 185-212.

Ferrari, E., Paz, A., \& Silva, A. C. (2015). Déficit hídrico e altas temperaturas no metabolismo da soja em semeaduras antecipadas. Nativa, 3(1), 67-77. https://doi.org/10.14583/2318-7670.v03n01a12

Finatto, J., Altmayer, T., Martini, M. C., Mariano, R. M., Basso, V., \& Hoehne, L. A. (2013). A importância da utilização da adubação orgânica na agricultura. Revista Destaques Acadêmicos, 5(4).

Ghobadi, M., Mohammadi, G., \& Jalalihonarmand, S. (2013). Antioxidant capacity, photosynthetic characteristics and water relations of sunflower (Helianthus annuus L.) cultivars in response to drought stress. Industrial Crops and Products, 50(1), 29-38. https://doi.org/10.1016/j.indcrop.2013.07.009

Gill, S. S., \& Tuteja, N. (2010). Reactive oxygen species and antioxidant machinery in abiotic stress tolerance in crop plants. Plant Physiology and Biochemistry, 48(12), 909-930. https://doi.org/10.1016/j.plaphy.2010. 08.016

Gonçalves, C. G. (2017). Modificações morfológicas, fisiológicas e seletividade da soja a diferentes herbicidas em resposta ao estresse hídrico (Unpublished doctoral thesis, UNESP, São Paulo, Brazil).

Guedes Filho, D. H., Chaves, L. H. G., Campos, V. B., Santos Júnior, J. A., \& Oliveira, J. T. L. (2011). Production of sunflower and biomass depending on available soil water and nitrogen levels. Iranica Journal of Energy \& Environment, 2(4), 313-319.

Gupta, P., Roy, S., \& Mahindrakar, A. B. (2012). Treatment of water using water hyacinth, water lettuce and vetiver Grass-A review. Resources and Environment, 2(5), 202-215. https://doi.org/10.5923/j.re.20120 205.04

Havir, E. \& Mchale, N. A. (1987). Biochemical and developmental characterization of multiple forms of catalases in tobacco leaves. Plant Physiology, 84(1), 450-455. https://doi.org/10.1104/pp.84.2.450

Hendges, F. B., Rambo, C. R., Alcassa, L. P., Liebl, J., Vendruscolo, E. C. G., \& Costa, A. (2015). Avaliação enzimática e fisiológica de plântulas de milho submetidas à seca. Revista Brasileira de Energias Renováveis, 4(2), 52-63. https://doi.org/10.5380/rber.v4i2.42287

Henry-Silva, G. G., Moura, R. S. T., \& Dantas, L. L. O. (2010). Richness and Distribution of Aquatic Macrophytes in Brasilian Semiarid Aquatic Ecosystems. Acta Limnologica Brasiliensia, 22(1), 147-156. https://doi.org/10.4322/actalb.02202004

Kar, M., \& Mishra, D. (1976). Catalase, peroxidase, and polyphenol oxidase activities during rice leafs enescence. Plant Physiology, 57(1), 315-319. https://doi.org/10.1104/pp.57.2.315 
Lira, M. A., Chagas, M. C. M., Bristot, G., Dantas, J. A., Holanda, J. S. De, \& Lima, J. M. P. (2009). Recomendações técnicas para o cultivo de girassol. EMPARN, Natal, Brasil.

Maia, J. M., Ferreira-Silva, S. L., Voigt, E. L., Macedo, C. D., Ponte, L. F. A., \& Silveira, J. A. G. (2012). Atividade de enzimas antioxidantes e inibição do crescimento radicular de feijão-caupi sob diferentes níveis de salinidade. Acta Botanica Brasilica, 26(2), 342-349. https://doi.org/10.1590/S0102-33062012000200010

Manivannan, P., Rajasekar, G. A. M., \& Somasundaram, R. (2016). Analysis of Antioxidant Enzyme activity in various genotypes of Helianthus annuus L. (Sunflower) under varied irrigation regimes. Food Biology, 3(1).

Melignani, E., De Cabo, L. I., \& Faggi, A. M. (2015). Copper uptake by Eichhornia crassipes exposed at high level concentrations. Environmental Science and Pollution Research, 22(11), 8307-8315. https://doi.org/ $10.1007 / \mathrm{s} 11356-014-3972-7$

Messchmidt, A. A., Bianchi, V. J., Zanandrea, I., Martinazzo, E. G., Radmann, E. B., \& Bacarin, M. A. (2015). Trocas gasosas e atividade antioxidante de porta enxertos de Prunus spp. submetidos ao estresse seco e alagamento. Revista de la Faculdad de Agronomia, 114(1), 71-81.

Nascimento, S. P., Bastos, E. A., Araújo, E. C. E., Freire Filho, F. R., \& Silva, E. M. (2011). Tolerância ao déficit hídrico em genótipos de feijão-caupi. Revista Brasileira de Engenharia Agrícola e Ambiental, 15(1), 853-860. https://doi.org/10.1590/S1415-43662011000800013

Niu, X., Song, L., Xiao, Y., \& Ge, W. (2017). Drought-tolerant plant growth-promoting rhizobacteria associated with foxtail millet in a semiarid agroecosystem and their potential in all evirating drought stress. Frontiers in Microbiology, 8(1), 2580. https://doi.org/10.3389/fmicb.2017.02580

Nobre, R. G., Gheyi, H. R., Soares, F. A. L., \& Cardoso, J. A. (2011). Produção de girassol sob estresse salino e adubação nitrogenada. Revista Brasileira de Ciência do Solo, 35(3), 929-937. https://doi.org/10.1590/ S0100-06832011000300027

Nobre, R. N., Lima, G. S., Raj, G. H., Araújo, E. B. G., \& Soares, A. A. (2017). Crescimento do girassol com águas de diferentes salinidades, fontes e doses de nitrogênio. Revista Brasileira de Agricultura Irrigada, 11(8), 2098-2110. https://doi.org/10.7127/rbai.v11n800685

Nunes Junior, F. H., Gondim, F. A., Freitas, V. S., Braga, B. B., Brito, P. O. B., \& Martins, K. (2017). Crescimento foliar e atividades das enzimas antioxidativas em plântulas de girassol suplementadas com percolado de aterro sanitário e submetidas a estresse hídrico. Revista Ambiente \& Água, 12(1), 71. 1980-993. https://doi.org/10.4136/ambi-agua.1964

Pedro, F., Maltchik, L., \& Bianchini Jr., I. (2006). Hydrologic cycleand dynamics of aquatic macrophytes in two intermittent Rivers of the semiarid region of Brasil. Brazilian Journal of Biology, 66(2b), 575-585. https://doi.org/10.1590/S1519-69842006000400002

Santos, J. C. C., Silva, C. H., Santos, C. S., Silva, C. S., Melo, E. B., \& Barros, A. C. (2014). Análise de crescimento e evapotranspiração da cultura do rabanete submetido a diferentes lâminas de água. Revista Verde de Agroecologia e Desenvolvimento Sustentável, 9(1), 151-156.

Santos, K. S., Montenegro, A. A., Almeida, B. G., Montenegro, S. M., Andrade, T., \& Robertson, V. (2010). Variabilidade espacial de atributos físicos em solos de vale aluvial no semiárido de Pernambuco. Revista Brasileira de Engenharia Agrícola e Ambiental, 16(8). https://doi.org/10.1590/S1415-43662012000800003

Santos, L. G., Souza, U. O., Carvalho, Z. S., Primo, D. C., \& Santos, A. R. (2015). Análise de crescimento do girassol em função do suprimento de fósforo e boro. Bioscience Journal, 31(1), $370-381$. https://doi.org/10.14393/BJ-v31n2a2015-22316

Shanab, S. M. M., Shalaby, E. A., Lightfoot, D. A., \& El-Shemy, H. A. (2010). Allelopathic Effects of Water Hyacinth (Eichhornia crassipes). PLoS One, 5(10), e13200. https://doi.org/10.1371/journal.pone.0013200

Silva, P. B. da. (2010). Aspectos fisiológicos de seis genótipos de cana-de-açúcar submetidos a estresse hídrico (Unpublished Master's Dissertation. Centro de Ciências Agrárias, Universidade Federal de Alagoas, Rio Largo, Brazil).

Souza, R. M., Nobre, R. G., Gheyi, H. R., Dias, N. S., \& Soares, F. A. L. (2010). Utilização de água residuárias e de adubação orgânica no cultivo do girassol. Revista Caatinga, 23(2), 125-133.

Villamagna, A. M., \& Murphy, B. R. (2010) Ecological and socio-economic impacts of invasive water hyacinth (Eichhornia crassipes): A review. Freshwater Biology, 55(2), 282-298. https://doi.org/10.1111/j.1365-2427. 2009.02294.x 
Vodyanitskii, Y. N., \& Shoba, S. A. (2015). Biogeochemistry of carbon, iron, and heavy metals in wetlands (analytical review). Moscow University Soil Science Bulletin, 70(3), 89-97. https://doi.org/10.3103/S01476 87415030072

\section{Copyrights}

Copyright for this article is retained by the author(s), with first publication rights granted to the journal.

This is an open-access article distributed under the terms and conditions of the Creative Commons Attribution license (http://creativecommons.org/licenses/by/4.0/). 